\title{
Procalcitonin-guided diagnosis and antibiotic stewardship revisited
}

Ramon Sager ${ }^{1,2}$, Alexander Kutz ${ }^{1,2}$, Beat Mueller ${ }^{1,2}$ and Philipp Schuetz ${ }^{1,2^{*}}$

\begin{abstract}
Several controlled clinical studies have evaluated the potential of the infection biomarker procalcitonin (PCT) to improve the diagnostic work-up of patients with bacterial infections and its influence on decisions regarding antibiotic therapy. Most research has focused on lower respiratory tract infections and critically ill sepsis patients. A clinical utility for PCT has also been found for patients with urinary tract infections, postoperative infections, meningitis, and patients with acute heart failure with possible superinfection (i.e., pneumonia). In these indications, PCT levels measured on hospital admission were found to substantially reduce the initiation of antibiotic treatment in low-risk situations (i.e., bronchitis, chronic obstructive pulmonary disease exacerbation). For more severe infections (i.e., pneumonia, sepsis), antibiotic stewardship by monitoring of PCT kinetics resulted in shorter antibiotic treatment durations with early cessation of therapy. Importantly, these strategies appear to be safe without increasing the risk for mortality, recurrent infections, or treatment failures. PCT kinetics also proved to have prognostic value correlating with disease severity (i.e., pancreatitis, abdominal infection) and resolution of illness (i.e., sepsis). Although promising findings have been published in these different types of infections, there are a number of limitations regarding PCT, including suboptimal sensitivity and/or specificity, which makes a careful interpretation of PCT in the clinical context mandatory. This narrative review aims to update clinicians on the strengths and limitations of PCT for patient management, focusing on research conducted within the last 4 years.
\end{abstract}

Keywords: Procalcitonin, Pneumonia, Respiratory tract infection, Sepsis, Antibiotic stewardship

\section{Background}

There are important limitations to consider when using conventional diagnostic markers, such as blood cultures and inflammatory markers (i.e., C-reactive protein $[C R P])$, for patients with a clinical suspicion of infection, particularly in regard to suboptimal sensitivity and specificity [1]. These limitations often leave physicians with ambiguity regarding the necessity of the use of antibiotic treatment. As a consequence, unnecessary and prolonged exposure to antimicrobial agents adversely affect patient outcomes (e.g., risk for Clostridium difficile infection), while inappropriate antibiotic therapy increases antibiotic resistance in patients, resulting in a public health threat. A growing body of evidence supports the use of the infection marker procalcitonin (PCT) to improve the diagnosis of bacterial infections and to

\footnotetext{
* Correspondence: schuetzph@gmail.com

${ }^{1}$ University Department of Medicine, Kantonsspital Aarau, Tellstrasse, CH-5001

Aarau, Switzerland

${ }^{2}$ Faculty of Medicine, University of Basel, Basel, Switzerland
}

indicate resolution of infection, thereby helping to monitor patients and guide antibiotic therapy.

Based on a review published in 2011 [2], this current narrative review aims to update clinicians on (promising) new indications for PCT in patient management by focusing on research studies published from 2012 to the end of 2016. The evidence from observational and interventional research is ordered by different types of infections and study designs. Proposed PCT cut-offs and the main conclusions of relevant studies are summarized in Table 1 and graphically displayed in Fig. 1.

\section{Infections of the respiratory tract}

Infections of the respiratory tract, including bronchitis, community-acquired pneumonia (CAP), and acute exacerbated chronic obstructive pulmonary disease (AECOPD), are the most important drivers for antibiotic (over-) treatment and thereby contribute to the increasing rate of antibiotic multi-resistance. The diagnosis of respiratory infections relies mainly on 
Table 1 Overview of studies investigating the use of procalcitonin in different types and sites of infections

\begin{tabular}{|c|c|c|c|c|c|c|c|}
\hline & Type of infection & $\begin{array}{l}\text { New studies } \\
\text { since } 2010 ?\end{array}$ & Study design & $\begin{array}{l}\text { PCT cut-off } \\
(\mu \mathrm{g} / \mathrm{L})\end{array}$ & $\begin{array}{l}\text { Benefit of } \\
\text { PCT use? }\end{array}$ & Main conclusions & $\begin{array}{l}\text { Selected references } \\
\text { since } 2012\end{array}$ \\
\hline \multirow[t]{6}{*}{ Pulmonary } & AECOPD & yes & $\begin{array}{l}\mathrm{RCT}(\mathrm{N}=120), \\
\text { meta-analysis }\end{array}$ & $<0.25$ & ++ & $\begin{array}{l}\text { PCT reduces initiation of antibiotic } \\
\text { treatment in the ED without } \\
\text { adverse outcomes }\end{array}$ & {$[7,12]$} \\
\hline & Asthma & yes & $\mathrm{RCT}(\mathrm{N}=216)$ & $<0.1-0.25$ & ++ & $\begin{array}{l}\text { PCT reduces initiation of antibiotic } \\
\text { treatment in the ED without adverse } \\
\text { outcomes }\end{array}$ & [89] \\
\hline & Bronchitis & $\begin{array}{l}\text { yes } \\
\text { (Registry) }\end{array}$ & $\begin{array}{l}\mathrm{RCT} \text {, real-life } \\
\text { (Registry) }\end{array}$ & $<0.1-0.25$ & ++ & $\begin{array}{l}\text { PCT reduces initiation of antibiotic } \\
\text { treatment in the ED without adverse } \\
\text { outcomes }\end{array}$ & {$[42]$} \\
\hline & $\begin{array}{l}\text { Community- } \\
\text { acquired } \\
\text { pneumonia }\end{array}$ & yes & $\begin{array}{l}\text { RCT, meta-analysis } \\
(\mathrm{N}=4467) \\
\text { real-life (Registry) }\end{array}$ & $\begin{array}{l}<0.1-0.25 ; 80- \\
90 \% \text { decrease }\end{array}$ & +++ & $\begin{array}{l}\text { PCT shortens length of antibiotic } \\
\text { therapy in the ED and hospital ward } \\
\text { without adverse outcomes }\end{array}$ & [7] \\
\hline & $\begin{array}{l}\text { Pulmonary } \\
\text { fibrosis }\end{array}$ & yes & $\mathrm{RCT}(\mathrm{N}=78)$ & $<0.25$ & ++ & $\begin{array}{l}\mathrm{PCT} \text { reduces initiation of antibiotic } \\
\text { treatment in the ED without adverse } \\
\text { outcomes }\end{array}$ & {$[15]$} \\
\hline & $\begin{array}{l}\text { Upper respiratory } \\
\text { tract infections }\end{array}$ & no & $\mathrm{RCT}(\mathrm{N}=458,702)$ & $<0.1-0.25$ & +++ & $\begin{array}{l}\mathrm{PCT} \text { reduces initiation of antibiotic } \\
\text { treatment in primary care without } \\
\text { adverse outcomes (non-inferiority) }\end{array}$ & {$[90,91]$} \\
\hline \multirow[t]{2}{*}{ Heart } & $\begin{array}{l}\text { Congestive heart } \\
\text { failure }\end{array}$ & yes & $\begin{array}{l}\text { Observational, RCT } \\
\text { (secondary analysis, } \\
N=110 \text { ) }\end{array}$ & $<0.21-0.25$ & ++ & $\begin{array}{l}\text { PCT helps in identification of bacterial } \\
\text { superinfection in acute heart failure, } \\
\text { may be helpful in guiding antibiotic } \\
\text { treatment }\end{array}$ & {$[38,43]$} \\
\hline & Endocarditis & no & $\begin{array}{l}\text { Observational, } \\
\text { meta-analysis }\end{array}$ & $<0.5$ & + & $\begin{array}{l}\mathrm{PCT} \text { is a predictor of poor outcome, } \\
\text { diagnostic value similar to CRP }\end{array}$ & {$[67,68]$} \\
\hline \multirow[t]{4}{*}{ Abdominal } & $\begin{array}{l}\text { Abdominal } \\
\text { infections with } \\
\text { peritonitis }\end{array}$ & yes & Observational & $\begin{array}{l}<0.5 ; 80 \% \\
\text { decrease }\end{array}$ & ++ & $\begin{array}{l}\text { PCT-guided therapy was associated } \\
\text { with lower antibiotic exposure with } \\
\text { no difference in mortality }\end{array}$ & {$[66]$} \\
\hline & Appendicitis & yes & $\begin{array}{l}\text { Observational, } \\
\text { meta-analysis }\end{array}$ & $N R$ & + & $\begin{array}{l}\text { PCT is a marker of complicated } \\
\text { appendicitis, low value for } \\
\text { diagnosing appendicitis }\end{array}$ & [92] \\
\hline & Pancreatitis & yes & $\mathrm{RCT}(\mathrm{N}=71)$ & $<0.5$ & ++ & $\begin{array}{l}\text { PCT reduces antibiotic exposure } \\
\text { compared to prophylactic antibiotic } \\
\text { treatment without adverse outcomes }\end{array}$ & {$[65]$} \\
\hline & $\begin{array}{l}\text { Urinary tract } \\
\text { infections }\end{array}$ & yes & $\mathrm{RCT}(\mathrm{N}=125)$ & $<0.25$ & ++ & $\begin{array}{l}\text { PCT reduces antibiotic exposure } \\
\text { without adverse effects }\end{array}$ & {$[47]$} \\
\hline \multirow[t]{3}{*}{ Blood } & $\begin{array}{l}\text { Blood stream } \\
\text { infection }\end{array}$ & yes & Observational & $<0.25-1.47$ & ++ & $\begin{array}{l}\text { PCT levels correlate with risk for } \\
\text { positive blood cultures }\end{array}$ & {$[19,27]$} \\
\hline & Neutropenia & yes & $\mathrm{RCT}(\mathrm{N}=62)$ & $N R$ & - & $\begin{array}{l}\text { PCT is not useful to manage } \\
\text { antibiotic therapy, but PCT was a } \\
\text { marker of bacteremia }\end{array}$ & [93] \\
\hline & $\begin{array}{l}\text { Severe sepsis/ } \\
\text { shock }\end{array}$ & yes & $\mathrm{RCT}(\mathrm{N}=1575)$ & $\begin{array}{l}<0.5 ; 80 \% \\
\text { decrease }\end{array}$ & +++ & $\begin{array}{l}\text { PCT reduces antibiotic exposure and } \\
3 \text { month mortality in the ICU }\end{array}$ & {$[30]$} \\
\hline \multirow[t]{2}{*}{ Postoperative } & $\begin{array}{l}\text { Postoperative } \\
\text { abdominal } \\
\text { infection }\end{array}$ & yes & $\begin{array}{l}\text { Observational, } \\
\text { meta-analysis }\end{array}$ & $N R$ & + & $\begin{array}{l}\text { Low PCT post-surgical ensure safe } \\
\text { discharge, } P C T \text { is similar to CRP }\end{array}$ & {$[58,59]$} \\
\hline & $\begin{array}{l}\text { Postoperative } \\
\text { infections }\end{array}$ & yes & $\begin{array}{l}\text { RCTs, } \\
\text { Observational }\end{array}$ & $<0.5-2.0$ & ++ & $\begin{array}{l}\text { Low PCT suggests absence of } \\
\text { perioperative infection and enables } \\
\text { early discharge }\end{array}$ & \\
\hline \multirow[t]{3}{*}{ Other } & Arthritis & yes & Observational & $<0.5$ & + & $\begin{array}{l}\text { PCT identifies infection in patients } \\
\text { with rheumatoid arthritis }\end{array}$ & [94] \\
\hline & Erysipelas & yes & Observational & $<0.1$ & + & PCT differentiates erysipelas from DVT & [81] \\
\hline & Meningitis & no & $\begin{array}{l}\text { RCT, meta-analysis } \\
(\mathrm{N}=2058)\end{array}$ & $<0.5$ & +++ & $\begin{array}{l}\mathrm{PCT} \text { reduces } \mathrm{AB} \text { treatment during viral } \\
\text { outbreak; serum } \mathrm{PCT} \text { with CSF lactate } \\
\text { reliably identifies bacterial meningitis }\end{array}$ & {$[72,74]$} \\
\hline
\end{tabular}

Abbreviations: $A B$ antibiotic, $A E C O P D$ acute exacerbation of chronic obstructive pulmonary disease, CSF cerebral spinal fluid, $C R P C$-reactive protein, $E D$ emergency department; ICU intensive care unit; NR not reported, $P C T$ procalcitonin, $R C T$ randomized controlled trial. The level of evidence in favor or against PCT for each infection was rated by two of the coauthors (PS, RSA) independently and disagreements were resolved by consensus. +: moderate evidence in favor of PCT; ++: good evidence in favor of PCT; +++: strong evidence in favor of PCT; -: no evidence in favor of PCT 


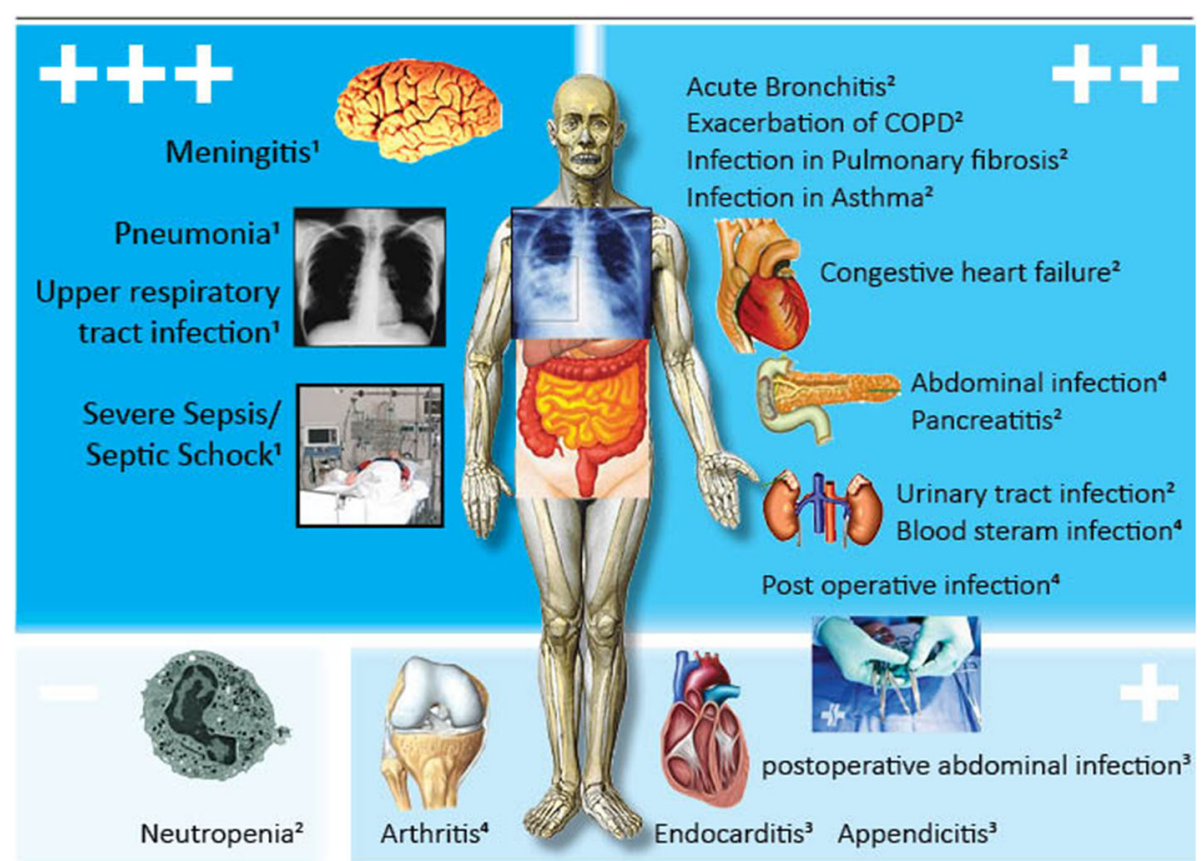

Fig. 1 Summary of evidence regarding procalcitonin (PCT) for diagnosis and antibiotic stewardship in organ-related infections. While for some infections, intervention studies have investigated benefit and harm of using PCT for diagnosis and antibiotic stewardship (left side), for other infections only results from diagnostic (observation) studies are available (right side). +: moderate evidence in favor of PCT; ++: good evidence in favor of PCT; +++: strong evidence in favor of PCT; - no evidence in favor of PCT

clinical criteria (e.g., cough, dyspnea, fever) and chest radiography to document infiltration of the lung [3]. Identification of the pathogen by culture or polymerase chain reaction (PCR) methods has low sensitivity, and thus may not rule out bacterial infection [3]. For some types of infections, such as Legionella, clinical scores can help to assess the risk of infection $[4,5]$. Several observational studies as well as interventional trials have established the usefulness of PCT in patients with respiratory infections.

A 2012 Cochrane meta-analysis based on individual patient data from 14 randomized controlled trials (RCTs) focused on effects of PCT in patients with respiratory infections [6,7]. The studies had somewhat similar PCT protocols with recommendations for or against initiation or continuation of antibiotic therapy based on initial PCT levels, PCT kinetics over time (i.e., $80 \%$ PCT decrease from peak), or both, in combination with the clinical presentation and resolution of illness (Figs. 2 and 3) [8]. The cut-offs were adapted to the clinical setting and the acuity of presentation, with cut-offs of $0.25(0.1) \mathrm{ng} / \mathrm{ml}$ in respiratory infections and $0.5 \mathrm{ng} / \mathrm{ml}$ in sepsis [9]. The meta-analysis found a strong reduction in the initial use of antibiotics, by around $60-70 \%$, for low-severity respiratory infection (i.e., bronchitis, upper respiratory infections, AECOPD) $[6,9,10]$. In cases of higher-severity respiratory infection (i.e., pneumonia), monitoring of PCT resulted in earlier cessation of antibiotic treatment with a relative reduction in the duration of antibiotic treatment of around $40 \%$ for pneumonia and around $25 \%$ in the critical care of patients with sepsis caused by lung infections. Based on these studies, recent respiratory infection guidelines state that "... biomarkers can guide treatment duration by the application of predefined stopping rules for antibiotics. It has been shown that such rules work even in most severe cases, including pneumonia with septic shock ..." [11], thereby emphasizing the concept of using a biomarker to guide the duration of antibiotic treatment.

An Italian RCT of patients with AECOPD published in 2016 found that a point-of-care PCT measurement was helpful in directing antibiotic therapy on admission [12]. In general, point-of-care technology has the advantage of high availability and short time to results for clinicians [13]. Patients randomized to the PCT group had a shorter antibiotic treatment course of 3.5 days compared to 8.5 for patients in the control group. The shorter duration in the PCT group did not negatively affect the resolution of illness or mortality.

Little research has so far focused on PCT use in patients with asthma and cystic fibrosis. A 2014 RCT in China of 216 patients with asthma also found PCT to be helpful in guiding antibiotic therapy, resulting in a reduction of prescribed antibiotics (48.9\% versus $87.8 \%$ ) 


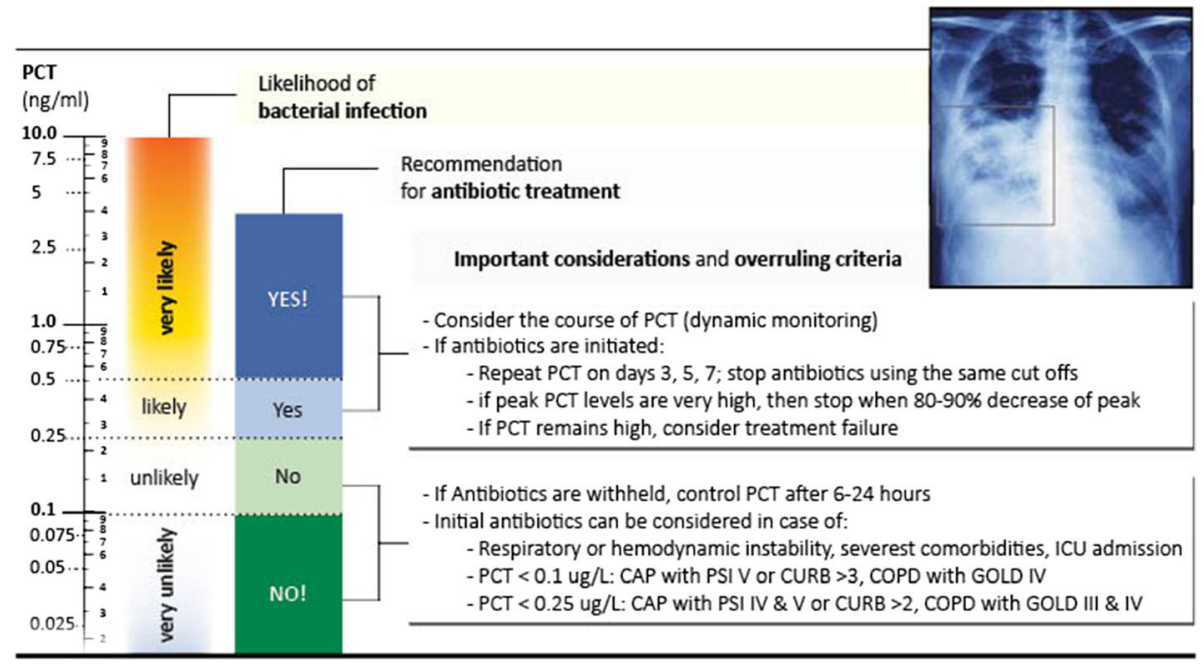

Fig. 2 Procalcitonin $(P C T)$ algorithm in patients with respiratory tract infections in the emergency department. The clinical algorithm for antibiotic stewardship in patients with respiratory tract infections in the emergency department encourages $(>0.5 \mathrm{ng} / \mathrm{ml}$ or $>0.25 \mathrm{ng} / \mathrm{ml})$ or discourages $(<0.1 \mathrm{ng} / \mathrm{ml}$ or $<0.25 \mathrm{ng} / \mathrm{ml})$ initiation or continuation of antibiotic therapy more or less based on specific PCT cut-off ranges. Abbreviations: $A B$ antibiotic, LRTI lower respiratory tract infection, ICU intensive care unit, PSI pneumonia severity score

and antibiotic exposure (relative risk 0.56, 95\% confidence interval [CI] 0.44-0.70) [14]. There were no significant differences between the two groups in clinical recovery; length of hospital stay; or clinical, laboratory, and spirometry outcomes. For patients with idiopathic pulmonary fibrosis (IPF), a small RCT in China of 78 patients found a shorter treatment length $(8.5 \pm 6.6$ days versus $14.2 \pm 5.2$ days) and fewer antibiotic prescriptions (26 versus 35 patients) in the PCT-guided group versus standard care. These small RCTs suggest that a PCTguided protocol is superior to standard care in patients with suspected infection and underlying pulmonary disease (asthma, COPD, IPF) and reduces antibiotic consumption [15].

Novel studies have looked at the effect of PCT testing in "real life" in patients with respiratory infections. The ProREAL study included 1759 patients from Switzerland, France, and the USA and validated previous results from well-controlled RCTs [16, 17]. Importantly, compliance in trials is often higher compared to compliance in real life and post-study registries are thus important to understand how physicians use new diagnostic tools in clinical

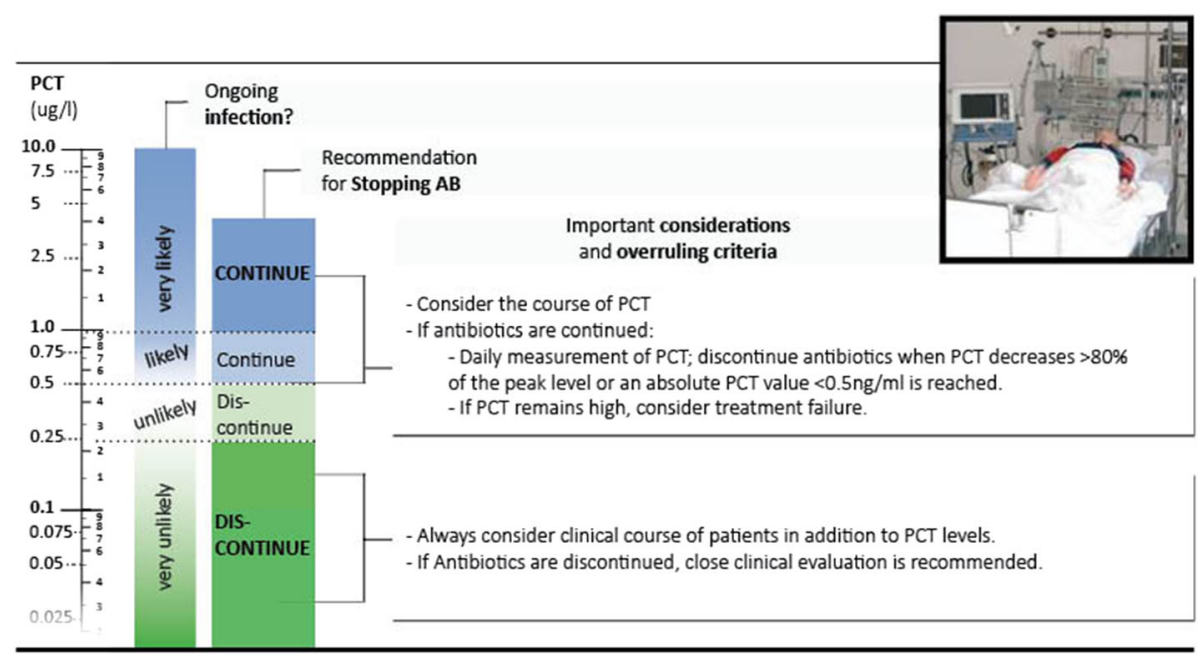

Fig. 3 Procalcitonin (PCT) algorithm in patients with sepsis in the intensive care unit (ICU). In critically ill patients in the ICU, cut-offs are higher and initial empiric antibiotic therapy should be encouraged in all patients with suspicion of sepsis. PCT cut-offs are helpful in the subsequent days after admission to shorten the course of antibiotic therapy in patients with clinical improvement 
practice. Algorithm compliance in the ProREAL study overall was $68.2 \%$, with differences between diagnoses, outpatients and inpatients, algorithm-experienced and algorithm-naive centers, and countries. Antibiotic therapy duration was significantly shorter if the PCT algorithm was followed compared with when it was overruled (5.9 versus 7.4 days; difference -1.51 days, $95 \%$ CI -2.04 to $-0.98 ; p<0.001)$. Another large propensity score-matched analysis investigated the impact of one to two PCT determinations on day 1 in the intensive care unit (ICU) on healthcare utilization and cost; this research database comprised 33,569 PCT-managed patients and 98,543 controls [18]. PCT utilization was associated with significantly decreased total and ICU length of stay, lower hospital costs, and lower total antibiotic exposure. Thus, real-life data showed similar effects compared to RCT data, emphasizing the importance of continuous education to increase knowledge and confidence in PCT protocols.

\section{Blood stream infection}

Currently no gold standard exists for detecting blood stream infection (BSI). Yet, this is a key factor in targeted therapy and may improve survival. Blood culture is the most reliable diagnostic modality and samples for culturing are collected routinely in patients in the emergency department. Blood cultures give important information about the type of microorganism and its susceptibility to antibiotic treatment. However, only a small proportion of cultures give positive results and $40-90 \%$ remain negative $[17,19]$. A large retrospective study from China found that only 440 of 2829 blood cultures (15.5\%) were positive [20]. Furthermore, time to result is long, which precludes important initial treatment decision-making.

Multiple clinical scores and biomarkers have been investigated for their ability to predict blood culture positivity. A meta-analysis from 2013, including 3244 critically ill patients classified using the former definition of either sepsis or systemic inflammatory response syndrome (SIRS) of non-infectious origin, pooled the diagnostic power of PCT. Studies between 1996 and 2011 were included and showed that PCT had a high discriminatory ability (area under the curve [AUC] of 0.85), with pooled sensitivity and specificity of 0.77 and 0.79 , respectively [21]. Similar results were reported in a large retrospective study from Korea in 2012 that included 3343 patients, showing an AUC of 0.76 for PCT in discriminating bacteremia from non-bacteremia [22].

In addition to biomarkers, clinical signs can also help in the assessment of the likelihood of culture positivity. One observational cohort study from 2015 that included 1083 patients who had blood culture drawn in the emergency department investigated several clinical scores and blood biomarkers, including the ability of PCT to predict blood culture sampling [19]. In blood culture-positive cases $(\mathrm{N}=104,9.6 \%)$ the Shapiro score and initial PCT concentration performed best, with AUCs of 0.729 and 0.803, respectively. Combining the Shapiro score and PCT significantly increased the AUC to 0.827. By limiting blood culture sampling only to patients with either a Shapiro score $\geq 4$ or PCT $>0.1 \mathrm{ng} / \mathrm{ml}$ would have reduced negative sampling by $20.2 \%$ while still identifying $100 \%$ of pathogens. A large retrospective study from 2016 in China including 2952 cases found an AUC of 0.713 for PCT, with an optimal cut-off value of $1.46 \mathrm{ng} / \mathrm{ml}$ for distinguishing negative from positive blood cultures (sensitivity 70\%, specificity $64.5 \%$ ) [20]. In contrast, an Austrian study published in 2014 that included 898 patients with 666 confirmed positive blood cultures (74.2\%) found that PCT performed only moderately, with an AUC of 0.675 . Even at a cut-off level of $0.1 \mathrm{ng} / \mathrm{ml}$, PCT failed to correctly identify 46 positive blood cultures (7\%) while reducing negative blood culture sampling by $20 \%$. The researchers concluded that the false negative ratio was too high to implement blood culture sampling by PCT only [23]. These controversial results point out the need for further studies on this topic.

Interestingly, studies have also investigated PCT to assess whether blood cultures that test positive have been contaminated. Several studies found that PCT showed good discrimination between BSI and contamination with an AUC of 0.86 [22, 24]. Additionally, in a PCR diagnostic (SeptiFast) test, a PCT value of $<0.37 \mathrm{ng} / \mathrm{ml}$ had a $99 \%$ negative predictive value for this assay [25]. Studies have also investigated how well PCT correlates with types of pathogens. Different PCT cut-off levels suggest different bacterial species, with higher concentrations for Gram-negative Bacteriaceae (AUC 0.81 at cut-off $6.47 \mathrm{ng} / \mathrm{ml}$ ) [20, 26]. Furthermore, PCT has been shown to be helpful in differentiating infectious disease from autoimmune disease. In SIRS patients with negative blood cultures, PCT can differentiate septic from non-septic causes (AUC 0.892). A PCT cut-off value of $1.47-2 \mathrm{ng} / \mathrm{ml}$ shows the best performance (sensitivity $92 \%$, specificity $83 \%)$ [27, 28].

\section{Sepsis, severe sepsis, and septic shock}

Sepsis, as defined by SIRS criteria and organ dysfunction, and septic shock are common diseases in the ICU and require fast and appropriate antimicrobial therapy. Multiple studies have investigated whether a PCTguided algorithm can optimize the therapeutic approach in these patients, mainly by monitoring PCT kinetics and stopping antibiotics once PCT has dropped to levels $<0.5 \mathrm{ng} / \mathrm{ml}$ or by at least $80-90 \%$ of the peak in combination with clinical improvement. A 2013 meta-analysis including 1075 patients with sepsis or septic shock found overall reduced antibiotic treatment courses (6 days versus 8 days) when PCT was used to guide 
therapy compared to routine care. There was no increase in 28-day or in-hospital mortality or in length of stay in the ICU or the hospital. The authors do stress that there was heterogeneity in PCT protocols across trials with regard to different cut-off values or different algorithms for medical or surgical patients [29]. A large RCT published in 2016 in the Netherlands evaluated the use of PCT to de-escalate and stop antibiotics in 1575 critically ill patients who had received antibiotics $<24 \mathrm{~h}$ before inclusion in the study for an assumed or proven infection [30]. The study found that the PCT-guided protocol shortened length of antibiotic treatment (5 days versus 7 days in the first 28 days of admission) and lowered 28-day mortality from 25 to $19.6 \%$ [30]. Although the cause of the reduced mortality remained unclear, a lower risk of antibiotic-associated side effects and improved therapeutic monitoring could have been factors [31]. Very similar results in a recently published RCT from Germany also found a lower antibiotic consumption using PCT, but no benefit in mortality [32].

Interestingly, a multicentre trial including 11 Australian ICUs and almost 400 patients found only a modest effect of PCT testing in regard to antibiotic reductions (median number of antibiotic treatment days 9 versus 11) [33]. The authors used a $0.1 \mathrm{ng} / \mathrm{ml}$ cut-off to stop antibiotic treatment, which may explain the differences to other sepsis trials that used a $0.5 \mathrm{ng} / \mathrm{ml}$ cut-off.

In addition, similar to other sepsis markers, PCT has been found to predict the severity of illness. A metaanalysis from 2015 showed a significant difference in PCT on day 1 and 3 between survivors and non-survivors. But cut-off values varied between studies and it was not possible to pool data to a common cut-off value. There have been several trials investigating prognostic scores to determine the severity of SIRS, such as the Predisposition, Insult, Response, Organ dysfunction (PIRO) model and the Mortality in Emergency Department Sepsis (MEDS) score $[34,35]$. An important consideration in septic patients is that renal impairment and a reduced glomerular filtration rate may lower PCT clearance and levels thus may be higher than expected [36, 37].

\section{Congestive heart failure}

Patients with congestive heart failure (CHF) often present to the ED with dyspnea. It can be challenging to differentiate acute heart failure from a lung infection. PCT may be helpful in this indication for ruling in or ruling out an infection [38-41]. PCT has thus been proposed as a promising marker for cardiologists [41]. A large study from China found that the severity of $\mathrm{CHF}$ was also a predictor for PCT levels in patients with infection complicated by heart failure [40]. A large observational study found a worse outcome in patients with a diagnosis of $\mathrm{CHF}$ and an elevated PCT concentration
$(>0.21 \mathrm{ng} / \mathrm{mL})$ if they were not treated with antibiotics $(p=0.046)$. Patients with low PCT values $(<0.05 \mathrm{ng} / \mathrm{mL})$ had a better outcome if they did not receive antibiotic therapy $(p=0.049)$. Similar results were also found in a secondary analysis of a previous randomized trial and it was speculated that more appropriate treatment decisions due to PCT monitoring could explain this effect (diuretic therapy with liquid restriction in case of acute heart failure versus antibiotics and fluids in case of infection) $[42,43]$. The role of PCT in the setting of decompensated $\mathrm{CHF}$ has potential and needs to be elucidated in future studies. Results from the IMPACT-EU trial may be of high relevance (https://clinicaltrials.gov/ct2/ show/NCT02392689).

\section{Urinary tract infection}

Several new publications have focused on the utility of PCT in urinary tract infection (UTI) with or without sepsis [44-46]. A threshold of $1.16 \mathrm{ng} / \mathrm{ml}$ was proposed by Julian-Jemenez et al. [44] as having the largest area under the receiver operating characteristic curve at 0.993 and therefore the most relevant in guiding medical decision-making [44]. The utility of PCT in this setting was also investigated in a Swiss RCT [47]. The study showed a reduction in antibiotic use of $30 \%$ compared to the standard treatment. The elaborated algorithm combined serum PCT concentration and quantitative pyuria measurements [47]. Patients were classified with uncomplicated or complicated UTI and as outpatients versus inpatients, resulting in different antibiotic administration, different length of treatment, or a monitored approach with measuring of PCT and degree of pyuria. There were no negative effects. The authors concluded that a PCT/pyuria-based approach is safe in terms of outcome and has the potential to reduce antibiotic consumption.

\section{Postsurgical infection}

A physiological rise in PCT concentration is observed in postoperative patients due to surgical stress-triggered inflammation. The highest values are measured on the second postoperative day and usually show a sharp decline thereafter. Therefore, very high initial levels or nondropping levels of PCT suggest postsurgical infection [48]. A chronological sampling was shown to be useful and superior to on-time sampling and predicted complications in the postoperative course [49]. Positive results for PCT were shown in studies of cardiopulmonary surgery, open aortic repair surgery, hip replacement, and liver transplantation [48-52]. Dong et al. found that PCT had a high discriminative power between septic and non-infective SIRS after cardiac surgery (cut-off value $0.47 \mathrm{ng} / \mathrm{ml}$ ) [53]. PCT was also found to be useful to confirm surgical success after necrotizing fasciitis 
[54]. In complicated abdominal infection after surgery, high PCT correlates with mortality rates [55]. In addition, PCT is also beneficial in the setting of postoperative fever [56]. Several observational studies have questioned the reliability of PCT in postoperative patients with intra-abdominal infection. Although the negative predictive value was found to be high, which may help to ensure early discharge [57], the specificity was quite low. Also, a meta-analysis including 2692 patients after colorectal surgery showed no advantage of PCT compared to CRP regarding diagnostic accuracy and mortality prediction [58]. This was confirmed recently in a similar large prospective study including 501 patients [59]. Thus, further investigation is needed in the surgical setting, and also to compare the accuracy and cost-effectiveness of PCT with other infection markers such as CRP.

\section{Abdominal disease and abdominal infection}

Several studies have investigated the use of PCT in patients with abdominal infection. In patients with liver cirrhosis, one study found that PCT could identify complications through bacterial infection [60, 61]. Similar results were found for acute pancreatitis, with PCT a good predictor of accompanied perforation or abscess [62-64]. In a small RCT of patients with acute pancreatitis, a PCT-guided antimicrobial approach was shown to be safe and effective compared to a control group that received prophylactic antibiotic treatment for 2 weeks [65]. Furthermore, in patients presenting with secondary peritonitis, PCT-guided therapy was shown to reduce antibiotic consumption by $50 \%$ [66]. There are currently no studies evaluating the role of PCT in infected diverticulosis and more studies are strongly needed in general to evaluate the use of PCT-guided treatment in abdominal infection.

\section{Endocarditis}

Few studies have investigated the use of serum PCT in infectious endocarditis. Nevertheless, one large metaanalysis by $\mathrm{Yu}$ et al. found that PCT was not superior compared to CRP, and therefore not suitable in routine diagnostic [67]. However, Cornelissen et al. found PCT useful in the prediction of poor outcome (cut-off $0.5 \mathrm{ng} /$ ml, sensitivity $73 \%$, specificity $79 \%$ ), with an odds ratio of 12.8 (95\% CI 2.5-66.2) for finding Staphylococcus aureus in blood cultures [68].

\section{Febrile neutropenia}

In patients with haematological malignancies with newly developed febrile neutropenia (FN), PCT is an accurate marker of infection as well as a predictor of severity [69, 70]. A 2015 meta-analysis provided the first large-scale clinical evidence on the validity of
PCT in discriminating bacterial infection from other cause of fever in patients with FN [71]. In this study of 1960 febrile episodes, a positive likelihood ratio of 5.49 was found for PCT being a good marker for infection. Overall, PCT had a specificity of 0.88 but low sensitivity of 0.65 , resulting in a suboptimal negative likelihood ratio of 0.4 . Taken together, PCT might be specific, but not sensitive, in differentiating severe bacterial infection from other systemic inflammation or viral infection. The authors state that, with regards clinical implications, the use of PCT is valuable as a diagnostic aid to confirm infection. However, the negative likelihood ratio (0.4) is unacceptably high for guiding antimicrobial therapy and PCT is therefore not suitable for predicting treatment cessation in patients with FN. Moreover, a recent study showed a significant correlation between initial PCT concentration and ICU admission (AUC 0.93) and mortality (AUC 0.86) [70].

\section{Meningitis}

Several older studies evaluated PCT-guided therapy in meningitis and determined that PCT-guided therapy reduces antimicrobial consumption during a viral outbreak [72]. Two recent meta-analyses confirmed PCT's accuracy in differentiating viral from bacterial meningitis [73, $74]$. The most recent meta-analysis from 2016 included 2058 subjects and showed a sensitivity of 0.95 (95\% CI 0.89-0.97), a specificity of 0.97 (95\% CI $0.89-0.99$ ), a positive likelihood ratio of 31.7 (95\% CI 8.0-124.8), and a negative likelihood ratio of 0.06 (95\% CI 0.03-0.11). The diagnostic performance was even better when combined with cerebrospinal fluid lactate. Serum PCT was found to be more sensitive and specific than cerebrospinal fluid PCT [74]. Furthermore, PCT was useful for prognostication of poor outcome, follow up of treatment, and for differentiating from tuberculous meningitis [75].

\section{Septic arthritis}

Several small studies have investigated the role of PCT in septic arthritis and bacterial osteomyelitis. In particular, in patients with rheumatologic disease, the differentiation between acute rheumatoid flare and infectious arthritis is of upmost importance. PCT was found to be a reliable marker at a cut-off of $0.4 \mathrm{ng} / \mathrm{ml}$ and is indicated especially if arthrocentesis cannot be performed [76]. The same is true in acute gouty arthritis, because PCT rises together with aseptic-gouty inflammation and can therefore be falsely positive [77, 78]. A PCT value beyond $0.5 \mathrm{ng} / \mathrm{ml}$ does not, however, rule out bacterial infection and appropriate treatment may be indicated [79]. Otherwise, PCT accuracy is highest when measured in fresh joint fluid [80]. We found no new studies evaluating PCT-guided antibiotic therapy in septic arthritis. 


\section{Erysipelas}

Few studies have investigated the use of PCT in local infections such as erysipelas. Early differentiation from similarly presenting deep vein thrombosis (DVT) based solely on clinical signs and symptoms is challenging. A 2015 study in Switzerland investigated the use of PCT to help physicians in discriminating between these infections. At a cut-off value of $0.1 \mathrm{ng} / \mathrm{ml}, \mathrm{PCT}$ had a sensitivity of 0.57 , a specificity of 0.82 , and a positive predictive value of 0.86 . Levels of PCT also correlated with the severity of erysipelas, with a stepwise increase according to SIRS criteria. Thus, PCT was found to be highly discriminant for differentiation between erysipelas and DVT but further research is warranted [81].

\section{Limitations}

This narrative review has limitations. First, we did not do a systematic review for each type of infection but have selected studies based on a PubMed search and the authors' expertise. Our conclusions may thus be too enthusiastic. Second, most of the studies did not blind patients and/or investigators and thus are subject to possible bias. Third, we focused on studies published between 2012 and mid-2016. Papers before or after this time frame may have been missed. We have also not discussed in detail other markers of infection such as CRP. However, there is a lack of welldone and large studies comparing the effect of both markers when used in the context of antibiotic stewardship [82, 83].

Importantly, $\mathrm{PCT}$ is far from being a perfect marker and levels must be evaluated in the context of a careful clinical and microbiological patient assessment. Because the kinetics of PCT are of particular diagnostic and prognostic importance, repeated measurements should be performed. This is particularly true for persistently sick patients and in situations in which antibiotics are withheld. The limitations of PCT include false-positive and false-negative results [84]. PCT levels can increase in the absence of a bacterial infection in patients with severe trauma or after surgery [84-86]. Here, PCT usually shows a rapid decline in follow-up measurements when the patient recovers. Also, patients with chronic renal failure can have a slower decrease in PCT levels. PCT levels can also be low in the early course or localised state of an infection, with later measurements showing an increase in levels. Again, repeated PCT measurements are advised in case of uncertainty. Another important consideration is the cost of measuring PCT. While some reviews found PCT to be cost-efficient in respiratory infections when antibiotics can be reduced by the measurement of this marker [87], this may not be true for other indications.

\section{Summary, future directions, and conclusions}

This update of a previous narrative review found several interesting new clinical settings in which PCT-guided therapy could help to reduce antibiotic exposure by decreasing either initiation or duration of treatment. Particularly, controlled clinical studies have found that PCT improves the management of patients with lower respiratory tract infections and critically ill sepsis patients, as well as patients with UTIs, postoperative infections, meningitis, and acute heart failure with possible superinfection (i.e., pneumonia). Recording PCT levels on hospital admission was found to substantially reduce the initiation of antibiotic treatment in low-risk situations (i.e., bronchitis, AECOPD). For more severe infections (i.e., pneumonia, sepsis), antibiotic stewardship by monitoring PCT kinetics resulted in shorter antibiotic treatment duration by early cessation of therapy. These strategies appear to be safe without increasing the risk for mortality, recurrent infections, or treatment failure. PCT kinetics have also proved to have prognostic value, correlating with disease severity (i.e., pancreatitis, abdominal infection) and resolution of illness (i.e., sepsis). While there is strong evidence regarding antibiotic stewardship in respiratory infection and sepsis, PCT has not been as well studied for other types of infections. Thus, future research should focus on non-respiratory infections and investigate whether PCT improves antibiotic decisions in these patients. PCT should also be compared to other markers, such as CRP, in regard to diagnostic accuracy and cost-effectiveness.

Emerging bacterial resistance to antimicrobial agents calls for more effective efforts to reduce the unnecessary and prolonged use of antibiotics in self-limiting nonbacterial and resolving diseases [88]. Healthcare professionals share a common goal of achieving symptom relief from infection as fast as possible and often see antibiotics as the best means to achieve this goal. This "one size fits all" approach, however, does not answer the basic questions of who truly benefits from antibiotic therapy and what would be the optimal duration of treatment. There is a growing body of literature supporting the use of PCT as a persuasive, evidence-based approach to a more rational use of antibiotics.

\author{
Acknowledgements \\ None. \\ Funding \\ There was no funding granted for this article.
}

Availability of data and materials

Not applicable.

Authors' contributions

RS and PS drafted the initial manuscript. AK and BM commented on the manuscript. All authors read and approved the final version. 


\section{Competing interests}

PS is supported by the Swiss National Science Foundation (SNSF Professorship, PP00P3_150531) and the Forschungsrat of the Kantonsspital Aarau (1410.000.058 and 1410.000.044). PS and BM received research support from BRAHMS/Thermo Fisher, BioMerieux, Roche, Abbott, Nestle, and Novo Nordisk. AK received research support from BRAHMS/Thermo Fisher, BioMerieux, and Novo Nordisk.

\section{Consent for publication}

Not applicable.

\section{Ethics approval and consent to participate}

Not applicable.

Received: 4 November 2016 Accepted: 13 January 2017

Published online: 24 January 2017

\section{References}

1. Mitsuma SF, Mansour MK, Dekker JP, Kim J, Rahman MZ, Tweed-Kent A, Schuetz P. Promising new assays and technologies for the diagnosis and management of infectious diseases. Clin Infectious Dis. 2013;56(7):996-1002.

2. Schuetz $P$, Albrich W, Mueller B. Procalcitonin for diagnosis of infection and guide to antibiotic decisions: past, present and future. BMC Med. 2011;9:107.

3. Musher DM, Thorner AR. Community-acquired pneumonia. New Engl J Med. 2014;371(17):1619-28.

4. Fiumefreddo R, Zaborsky R, Haeuptle J, Christ-Crain M, Trampuz A, Steffen I, Frei R, Muller B, Schuetz P. Clinical predictors for Legionella in patients presenting with community-acquired pneumonia to the emergency department. BMC Pulm Med. 2009;9:4.

5. Haubitz S, Hitz F, Graedel L, Batschwaroff M, Wiemken TL, Peyrani P, Ramirez JA, Fux CA, Mueller B, Schuetz P. Ruling out Legionella in communityacquired pneumonia. Am J Med. 2014;127(10):1010. e1011-19.

6. Schuetz P, Muller B, Christ-Crain M, Stolz D, Tamm M, Bouadma L, Luyt CE, Wolff M, Chastre J, Tubach F, et al. Procalcitonin to initiate or discontinue antibiotics in acute respiratory tract infections. Cochrane Database Syst Rev. 2012;9(9), CD007498.

7. Schuetz P, Briel M, Christ-Crain M, Stolz D, Bouadma L, Wolff M, Luyt CE, Chastre J, Tubach F, Kristoffersen KB, et al. Procalcitonin to guide initiation and duration of antibiotic treatment in acute respiratory infections: an individual patient data meta-analysis. Clin Infect Dis. 2012;55(5):651-62.

8. Schuetz P, Christ-Crain M, Thomann R, Falconnier C, Wolbers M, Widmer I, Neidert S, Fricker T, Blum C, Schild U, et al. Effect of procalcitonin-based guidelines vs standard guidelines on antibiotic use in lower respiratory tract infections: the ProHOSP randomized controlled trial. JAMA. 2009;302(10): 1059-66.

9. Schuetz P, Chiappa V, Briel M, Greenwald JL. Procalcitonin algorithms for antibiotic therapy decisions: a systematic review of randomized controlled trials and recommendations for clinical algorithms. Arch Inter Med. 2011; 171(15):1322-31

10. Schuetz P, Briel M, Mueller B. Clinical outcomes associated with procalcitonin algorithms to guide antibiotic therapy in respiratory tract infections. JAMA. 2013;309(7):717-8.

11. Woodhead M, Blasi F, Ewig S, Garau J, Huchon M, Leven M, Ortqvist A Schaberg T, Torres A, Read R, et al. Guidelines for the management of adult lower respiratory tract infections. Clin Microbiol Infect. 2011;17 Suppl 6:E1-E59.

12. Corti C, Fally M, Fabricius-Bjerre A, Mortensen K, Jensen BN, Andreassen HF, Porsbjerg C, Knudsen JD, Jensen JU. Point-of-care procalcitonin test to reduce antibiotic exposure in patients hospitalized with acute exacerbation of COPD. Int J Chron Obstruct Pulmon Dis. 2016;11:1381-9.

13. Kutz A, Hausfater P, Oppert M, Alan M, Grolimund E, Gast C, Alonso C, Wissmann C, Kuehn C, Bernard M, et al. Comparison between B.R.A.H.M.S PCT direct, a new sensitive point-of-care testing device for rapid quantification of procalcitonin in emergency department patients and established reference methods - a prospective multinational trial. Clin Chem Lab Med. 2016;54(4):577-84.

14. Bafadhel M, Clark TW, Reid C, Medina MJ, Batham S, Barer MR, Nicholson KG, Brightling CE. Procalcitonin and C-reactive protein in hospitalized adult patients with community-acquired pneumonia or exacerbation of asthma or COPD. Chest. 2011;139(6):1410-8.
15. Ding J, Chen Z, Feng K. Procalcitonin-guided antibiotic use in acute exacerbations of idiopathic pulmonary fibrosis. Int J Med Sci. 2013;10(7): 903-7.

16. Dusemund F, Bucher B, Meyer S, Thomann R, Kuhn F, Bassetti S, Sprenger $M$, Baechli $E$, Sigrist T, Schwietert $M$, et al. Influence of procalcitonin on decision to start antibiotic treatment in patients with a lower respiratory tract infection: insight from the observational multicentric ProREAL surveillance. Eur J Clin Microbiol Infect Dis. 2013;32(1):51-60.

17. Vincent JL, Sakr Y, Sprung CL, Ranieri VM, Reinhart K, Gerlach H, Moreno R Carlet J, Le Gall JR, Payen D, et al. Sepsis in European intensive care units: results of the SOAP study. Crit Care Med. 2006;34(2):344-53.

18. Balk RA, Kadri SS, Cao Z, Robinson SB, Lipkin C, Bozzette SA. Effect of procalcitonin testing on healthcare utilization and costs in critically ill patients in the United States. Chest. 2017;151(1):23-33.

19. Laukemann S, Kasper N, Kulkarni P, Steiner D, Rast AC, Kutz A, Felder S, Haubitz S, Faessler L, Huber A, et al. Can we reduce negative blood cultures with clinical scores and blood markers? Results from an observational cohort study. Medicine (Baltimore). 2015;94(49), e2264.

20. Yu Y, Li XX, Jiang LX, Du M, Liu ZG, Cen ZR, Wang H, Guo ZH, Chang P. Procalcitonin levels in patients with positive blood culture, positive body fluid culture, sepsis, and severe sepsis: a cross-sectional study. Infect Dis (Lond). 2016;48(1):63-9.

21. Wacker C, Prkno A, Brunkhorst FM, Schlattmann P. Procalcitonin as a diagnostic marker for sepsis: a systematic review and meta-analysis. Lancet Infect Dis. 2013;13(5):426-35.

22. Jeong S, Park Y, Cho Y, Kim HS. Diagnostic utilities of procalcitonin and Creactive protein for the prediction of bacteremia determined by blood culture. Clin Chim Acta. 2012;413(21-22):1731-6.

23. Hoenigl M, Raggam RB, Wagner J, Prueller F, Grisold AJ, Leitner E, Seeber K, Prattes J, Valentin T, Zollner-Schwetz I, et al. Procalcitonin fails to predict bacteremia in SIRS patients: a cohort study. Int J Clin Pract. 2014;68(10): 1278-81.

24. Oksuz L, Somer A, Salman N, Erk O, Gurler N. Procalcitonin and C-reactive protein in differantiating to contamination from bacteremia. Braz $\mathrm{J}$ Microbiol. 2014;45(4):1415-21.

25. Mencacci A, Leli C, Cardaccia A, Meucci M, Moretti A, D'Alo F, Farinelli S, Pagliochini R, Barcaccia M, Bistoni F. Procalcitonin predicts real-time PCR results in blood samples from patients with suspected sepsis. PLoS One. 2012;7(12), e53279.

26. Guo SY, Zhou Y, Hu QF, Yao J, Wang H. Procalcitonin is a marker of Gram-negative bacteremia in patients with sepsis. Am J Med Sci. 2015; 349(6):499-504.

27. Anand D, Das S, Bhargava S, Srivastava LM, Garg A, Tyagi N, Taneja S, Ray S. Procalcitonin as a rapid diagnostic biomarker to differentiate between culture-negative bacterial sepsis and systemic inflammatory response syndrome: a prospective, observational, cohort study. J Crit Care. 2015;30(1): 218e7-218e12.

28. Tian G, Pan SY, Ma G, Liao W, Su QG, Gu BC, Qin K. Serum levels of procalcitonin as a biomarker for differentiating between sepsis and systemic inflammatory response syndrome in the neurological intensive care unit. J Clin Sci. 2014;21(7):1153-8.

29. Prkno A, Wacker C, Brunkhorst FM, Schlattmann P. Procalcitonin-guided therapy in intensive care unit patients with severe sepsis and septic shock-a systematic review and meta-analysis. Crit Care. 2013;17(6):R291.

30. de Jong E, van Oers JA, Beishuizen A, Vos P, Vermeijden WJ, Haas LE, Loef BG, Dormans T, van Melsen GC, Kluiters YC, et al. Efficacy and safety of procalcitonin guidance in reducing the duration of antibiotic treatment in critically ill patients: a randomised, controlled, open-label trial. Lancet Infect Dis. 2016;16(7):819-27.

31. Schuetz P, Mueller B. Procalcitonin in critically ill patients: time to change guidelines and antibiotic use in practice. Lancet Infect Dis 2016;16(7):758-60.

32. Bloos F, Trips E, Nierhaus A, Briegel J, Heyland DK, Jaschinski U, Moerer O, Weyland A, Marx G, Grundling M, et al. Effect of sodium selenite administration and procalcitonin-guided therapy on mortality in patients with severe sepsis or septic shock: a randomized clinical trial. JAMA Intern Med. 2016;176(9):1266-76.

33. Shehabi Y, Sterba M, Garrett PM, Rachakonda KS, Stephens D, Harrigan P, Walker A, Bailey MJ, Johnson B, Millis D, et al. Procalcitonin algorithm in critically ill adults with undifferentiated infection or suspected sepsis. A randomized controlled trial. Am J Resp Crit Care Med. 2014;190(10):1102-10. 
34. Wang T, Cui YL, Chu ZX, Liu J, Ban Y, Li TS. Value of a model based on PIRO conception in predicting the prognosis in critical patients. Zhonghua Wei Zhong Bing Ji Jiu Yi Xue. 2013;25(12):729-33.

35. Zhao Y, Li C, Jia Y. Evaluation of the Mortality in Emergency Department Sepsis score combined with procalcitonin in septic patients. Am J Emerg Med. 2013;31(7):1086-91.

36. Hattori T, Nishiyama H, Kato H, Ikegami S, Nagayama M, Asami S, Usami M, Suzuki M, Murakami I, Minoshima M, et al. Clinical value of procalcitonin for patients with suspected bloodstream infection. Am J Clin Pathol. 2014; 141(1):43-51.

37. Heredia-Rodriguez M, Bustamante-Munguira J, Fierro I, Lorenzo M, Jorge Monjas P, Gomez-Sanchez E, Alvarez FJ, Bergese SD, Eiros JM, BermejoMartin JF, et al. Procalcitonin cannot be used as a biomarker of infection in heart surgery patients with acute kidney injury. J Crit Care. 2016;33:233-9.

38. Maisel A, Neath SX, Landsberg J, Mueller C, Nowak RM, Peacock WF, Ponikowski P, Mockel M, Hogan C, Wu AH, et al. Use of procalcitonin for the diagnosis of pneumonia in patients presenting with a chief complaint of dyspnoea: results from the BACH (Biomarkers in Acute Heart Failure) trial. Eur J Heart Fail. 2012;14(3):278-86.

39. Demissei BG, Cleland JG, O'Connor CM, Metra M, Ponikowski P, Teerlink JR, Davison B, Givertz MM, Bloomfield DM, Dittrich $H$, et al. Procalcitonin-based indication of bacterial infection identifies high risk acute heart failure patients. Int J Cardiol. 2016;204:164-71.

40. Wang W, Zhang X, Ge N, Liu J, Yuan H, Zhang P, Liu W, Wen D. Procalcitonin testing for diagnosis and short-term prognosis in bacterial infection complicated by congestive heart failure: a multicenter analysis of 4,698 cases. Crit Care. 2014;18(1):R4.

41. Schuetz P, Daniels LB, Kulkarni P, Anker SD, Mueller B. Procalcitonin: A new biomarker for the cardiologist. Int J Cardiol. 2016;223:390-7.

42. Albrich WC, Dusemund F, Bucher B, Meyer S, Thomann R, Kuhn F, Bassetti S, Sprenger M, Bachli $E$, Sigrist $T$, et al. Effectiveness and safety of procalcitonin-guided antibiotic therapy in lower respiratory tract infections in "real life": an international, multicenter poststudy survey (ProREAL). Arch Intern Med. 2012;172(9):715-22

43. Schuetz P, Kutz A, Grolimund E, Haubitz S, Demann D, Vogeli A, Hitz F, Christ-Crain $M$, Thomann $R$, Falconnier $C$, et al. Excluding infection through procalcitonin testing improves outcomes of congestive heart failure patients presenting with acute respiratory symptoms: results from the randomized ProHOSP trial. Int J Cardiol. 2014;175(3):464-72.

44. Julian-Jimenez A, Gutierrez-Martin P, Lizcano-Lizcano A, Lopez-Guerrero MA, Barroso-Manso A, Heredero-Galvez E. Usefulness of procalcitonin and Creactive protein for predicting bacteremia in urinary tract infections in the emergency department. Actas Urol Esp. 2015;39(8):502-10.

45. Lee H, Lee YS, Jeong R, Kim YJ, Ahn S. Predictive factors of bacteremia in patients with febrile urinary tract infection: an experience at a tertiary care center. Infection. 2014;42(4):669-74

46. Hosokawa Y, Takenaga M, Itami Y, Shinohara M, Takada S, Hayashi Y, Hashimura M, Fujimoto K, Hirao Y. [Clinical utility of measurement of procalcitonin for diagnosis of urosepsis]. Hinyokika Kiyo. 2012;58(10):539-42.

47. Drozdov D, Schwarz S, Kutz A, Grolimund E, Rast AC, Steiner D, Regez K, Schild U, Guglielmetti M, Conca A, et al. Procalcitonin and pyuria-based algorithm reduces antibiotic use in urinary tract infections: a randomized controlled trial. BMC Med. 2015;13:104.

48. Bouaicha S, Blatter S, Moor BK, Spanaus K, Dora C, Werner CM. Early serum procalcitonin level after primary total hip replacement. Mediators Inflamm. 2013;2013:927636

49. Amin DN, Pruitt JC, Schuetz P. Influence of major cardiopulmonary surgery on serum levels of procalcitonin and other inflammatory markers. Anaesth Intensive Care. 2012;40(5):760-6.

50. Varetto G, Castagno C, Trucco A, Frola E, Bert F, Scozzari G, Rispoli P. Serum procalcitonin as a valuable diagnostic tool in the early detection of infectious complications after open abdominal aortic repair. Annals Vasc Surg. 2016;34:111-8

51. Kaido T, Ogawa K, Fujimoto Y, Mori A, Hatano E, Okajima H, Uemoto S. Perioperative changes of procalcitonin levels in patients undergoing liver transplantation. Transpl Infect Dis. 2014;16(5):790-6.

52. Kallel S, Abid M, Jarraya A, Abdenadher M, Mnif E, Frikha I, Ayadi F, Karoui A. Kinetics, diagnostic and prognostic value of procalcitonin after cardiac surgery. Ann Biol Clin. 2012;70(5):567-80.

53. Dong Z, Jianxin Z, Haraguchi G, Arai H, Mitaka C. Procalcitonin for the differential diagnosis of infectious and non-infectious systemic inflammatory response syndrome after cardiac operation. Zhonghua Wei Zhong Bing Ji Jiu Yi Xue. 2014;26(7):478-9.

54. Friederichs J, Hutter M, Hierholzer C, Novotny A, Friess H, Buhren V, Hungerer S. Procalcitonin ratio as a predictor of successful surgical treatment of severe necrotizing soft tissue infections. Am J Surg. 2013; 206(3):368-73.

55. Suarez-de-la-Rica A, Maseda E, Anillo V, Tamayo E, Garcia-Bernedo CA, Ramasco F, Hernandez-Gancedo C, Lopez-Tofino A, Gimenez MJ, Granizo JJ, et al. Biomarkers (procalcitonin, $C$ reactive protein, and lactate) as predictors of mortality in surgical patients with complicated intra-abdominal infection. Surg Infect. 2015;16(3):346-51.

56. Amin DN, Pruitt JC, Schuetz P. Influence of major cardiopulmonary surgery on serum levels of procalcitonin and other inflammatory markers. Anaesthesia and intensive care. 2012;40(5):760-6.

57. Dominguez-Comesana E, Lopez-Gomez V, Estevez-Fernandez SM, Marino Padin E, Ballinas-Miranda J, Carrera-Dacosta E, Pinon-Cimadevila MA, Barreiro-Morandeira F. Procalcitonin and C-reactive protein as early indicators of postoperative intra-abdominal infection after surgery for gastrointestinal cancer. Cir Esp. 2014;92(4):240-6.

58. Cousin F, Ortega-Deballon P, Bourredjem A, Doussot A, Giaccaglia V, Fournel I. Diagnostic accuracy of procalcitonin and C-reactive protein for the early diagnosis of intra-abdominal infection after elective colorectal surgery: a meta-analysis. Ann Surg. 2016;264(2):252-6.

59. Facy O, Paquette B, Orry D, Binquet C, Masson D, Bouvier A, Fournel I, Charles PE, Rat P, Ortega-Deballon P. Diagnostic accuracy of inflammatory markers as early predictors of infection after elective colorectal surgery: results from the IMACORS Study. Ann Surg. 2016;263(5):961-6.

60. Villarreal E, Vacacela K, Gordon M, Calabuig C, Alonso R, Ruiz J, Kot P, Babiloni D, Ramirez P. Usefulness of procalcitonin for diagnosing infection in critically ill patients with liver cirrhosis. Med Intensiva. 2016:40(2):84-9.

61. Cai ZH, Fan CL, Zheng JF, Zhang X, Zhao WM, Li B, Li L, Dong PL, Ding HG. Measurement of serum procalcitonin levels for the early diagnosis of spontaneous bacterial peritonitis in patients with decompensated liver cirrhosis. BMC Infect Dis. 2015;15:55.

62. Staubli SM, Oertli D, Nebiker CA. Laboratory markers predicting severity of acute pancreatitis. Crit Rev Clin Lab Sci. 2015;52(6):273-83.

63. Woo SM, Noh MH, Kim BG, Hsing CT, Han JS, Ryu SH, Seo JM, Yoon HA, Jang JS, Choi SR, et al. Comparison of serum procalcitonin with Ranson, APACHE-II, Glasgow and Balthazar CT severity index scores in predicting severity of acute pancreatitis. Korean J Gastroenterol. 2011:58(1):31-7.

64. Yamashita H, Yuasa N, Takeuchi E, Goto Y, Miyake H, Miyata K, Kato H, Ito M. Diagnostic value of procalcitonin for acute complicated appendicitis. Nagoya J Med Sci. 2016;78(1):79-88.

65. Qu R, Ji Y, Ling Y, Ye CY, Yang SM, Liu YY, Yang RY, Luo YF, Guo Z. Procalcitonin is a good tool to guide duration of antibiotic therapy in patients with severe acute pancreatitis. A randomized prospective singlecenter controlled trial. Saudi Med J. 2012;33(4):382-7.

66. Maseda E, Suarez-de-la-Rica A, Anillo V, Tamayo E, Garcia-Bernedo CA Ramasco F, Villagran MJ, Maggi G, Gimenez MJ, Aguilar L, et al. Procalcitonin-guided therapy may reduce length of antibiotic treatment in intensive care unit patients with secondary peritonitis: a multicenter retrospective study. J Crit Care. 2015;30(3):537-42.

67. Yu CW, Juan LI, Hsu SC, Chen CK, Wu CW, Lee CC, Wu JY. Role of procalcitonin in the diagnosis of infective endocarditis: a meta-analysis. Am J Emerg Med. 2013;31(6):935-41.

68. Cornelissen CG, Frechen DA, Schreiner K, Marx N, Kruger S. Inflammatory parameters and prediction of prognosis in infective endocarditis. BMC Infect Dis. 2013;13:272.

69. Fu Y, Jiang H, Li LX, Chen J, Zhang JL, Wang LL. Application value of procalcitonin and immune inflammatory factors for prediction of bacteraemia in patients with hematologic malignancy combined with febrile neutropenia. Zhongguo Shi Yan Xue Ye Xue Za Zhi. 2013;21(5):1296-300.

70. Liu X, Wang DF, Fang Y, Ye WF, Liu S, Lou N. Initial procalcitonin level predicts infection and its outcome in patients with non-Hodgkin lymphoma with febrile neutropenia. Leuk Lymphoma. 2015;56(1):85-91.

71. Wu CW, Wu JY, Chen CK, Huang SL, Hsu SC, Lee MT, Chang SS, Lee CC. Does procalcitonin, C-reactive protein, or interleukin- 6 test have a role in the diagnosis of severe infection in patients with febrile neutropenia? A systematic review and meta-analysis. Support Care Cancer. 2015;23(10): 2863-72. 
72. Marc E, Menager C, Moulin F, Stos B, Chalumeau M, Guerin S, Lebon P, Brunet F, Raymond J, Gendrel D. Procalcitonin and viral meningitis: reduction of unnecessary antibiotics by measurement during an outbreak. Arch Pediatr. 2002:9(4):358-64.

73. Vikse J, Henry BM, Roy J, Ramakrishnan PK, Tomaszewski KA, Walocha JA. The role of serum procalcitonin in the diagnosis of bacterial meningitis in adults: a systematic review and meta-analysis. Int J Infect Dis. 2015;38:68-76.

74. Wei TT, Hu ZD, Qin BD, Ma N, Tang QQ, Wang LL, Zhou L, Zhong RQ. Diagnostic accuracy of procalcitonin in bacterial meningitis versus nonbacterial meningitis: a systematic review and meta-analysis. Medicine. 2016;95(11), e3079.

75. Kim J, Kim SE, Park BS, Shin KJ, Ha SY, Park J, Park KM. Procalcitonin as a diagnostic and prognostic factor for tuberculosis meningitis. J Clin Neurol. 2016;12(3):332-9.

76. Paosong S, Narongroeknawin P, Pakchotanon R, Asavatanabodee P, Chaiamnuay $S$. Serum procalcitonin as a diagnostic aid in patients with acute bacterial septic arthritis. Int J Rheum Dis. 2015;18(3):352-9.

77. Zhang J, Liu J, Long L, Zhou Q, Cheng J, Zhou B. Value of procalcitonin measurement in the diagnosis of bacterial infections in patients with fever and flare of chronic gouty arthritis. Zhonghua Yi Xue Za Zhi. 2015;95(31): 2556-9.

78. Liu W, Sigdel KR, Wang Y, Su Q, Huang Y, Zhang YL, Chen J, Duan L, Shi G. High level serum procalcitonin associated gouty arthritis susceptibility: from a Southern Chinese Han population. PLoS One. 2015;10(7), e0132855.

79. Sato H, Tanabe N, Murasawa A, Otaki Y, Sakai T, Sugaya T, Ito S, Otani H, Abe A, Ishikawa $\mathrm{H}$, et al. Procalcitonin is a specific marker for detecting bacterial infection in patients with rheumatoid arthritis. J Rheumatol. 2012; 39(8):1517-23.

80. Wang C, Zhong D, Liao Q, Kong L, Liu A, Xiao H. Procalcitonin levels in fresh serum and fresh synovial fluid for the differential diagnosis of knee septic arthritis from rheumatoid arthritis, osteoarthritis and gouty arthritis. Exp Ther Med. 2014;8(4):1075-80.

81. Rast AC, Knobel D, Faessler L, Kutz A, Felder S, Laukemann S, Steiner D, Haubitz S, Fux CA, Huber A, et al. Use of procalcitonin, C-reactive protein and white blood cell count to distinguish between lower limb erysipelas and deep vein thrombosis in the emergency department: a prospective observational study. J Dermatol. 2015;42(8):778-85.

82. Meili M, Kutz A, Briel M, Christ-Crain M, Bucher HC, Mueller B, Schuetz P. Infection biomarkers in primary care patients with acute respiratory tract infections-comparison of procalcitonin and C-reactive protein. BMC Pulm Med. 2016;16(1):43.

83. Meili M, Muller B, Kulkarni P, Schutz P. Management of patients with respiratory infections in primary care: procalcitonin, C-reactive protein or both? Expert Rev Respir Med. 2015;9(5):587-601.

84. Christ-Crain M, Muller B. Procalcitonin in bacterial infections-hype, hope, more or less? Swiss Med Wkly. 2005;135(31-32):451-60.

85. Uzzan B, Cohen R, Nicolas P, Cucherat M, Perret GY. Procalcitonin as a diagnostic test for sepsis in critically ill adults and after surgery or trauma: a systematic review and meta-analysis. Crit Care Med. 2006;34(7):1996-2003.

86. Hunziker S, Hugle T, Schuchardt K, Groeschl I, Schuetz P, Mueller B, Dick W, Eriksson $U$, Trampuz A. The value of serum procalcitonin level for differentiation of infectious from noninfectious causes of fever after orthopaedic surgery. J Bone Joint Surg. 2010;92(1):138-48.

87. Schuetz P, Balk R, Briel M, Kutz A, Christ-Crain M, Stolz D, Bouadma L, Wolff $M$, Kristoffersen KB, Wei L, et al. Economic evaluation of procalcitoninguided antibiotic therapy in acute respiratory infections: a US health system perspective. Clin Chem Lab Med. 2015;53(4):583-92.

88. Whitney CG, Farley MM, Hadler J, Harrison LH, Lexau C, Reingold A, Lefkowitz L, Cieslak PR, Cetron M, Zell ER, et al. Increasing prevalence of multidrug-resistant Streptococcus pneumoniae in the United States. New Engl J Med. 2000;343(26):1917-24.

89. Long W, Li LJ, Huang GZ, Zhang XM, Zhang YC, Tang JG, Zhang Y, Lu G. Procalcitonin guidance for reduction of antibiotic use in patients hospitalized with severe acute exacerbations of asthma: a randomized controlled study with 12-month follow-up. Crit Care. 2014;18(5):471.

90. Burkhardt O, Ewig S, Haagen U, Giersdorf S, Hartmann O, Wegscheider K, Hummers-Pradier E, Welte T. Procalcitonin guidance and reduction of antibiotic use in acute respiratory tract infection. Eur Respir J. 2010;36(3): 601-7.

91. Briel M, Schuetz P, Mueller B, Young J, Schild U, Nusbaumer C, Periat $P$, Bucher HC, Christ-Crain M. Procalcitonin-guided antibiotic use vs a standard approach for acute respiratory tract infections in primary care. Arch Intern Med. 2008;168(18):2000-7. discussion 2007-8.

92. Yu CW, Juan LI, Wu MH, Shen CJ, Wu JY, Lee CC. Systematic review and meta-analysis of the diagnostic accuracy of procalcitonin, C-reactive protein and white blood cell count for suspected acute appendicitis. Br J Surg. 2013;100(3):322-9.

93. Lima SS, Nobre V, de Castro Romanelli RM, Clemente WT, da Silva Bittencourt HN, Melo AC, Salomao LC, Serufo JC. Procalcitonin-guided protocol is not useful to manage antibiotic therapy in febrile neutropenia: a randomized controlled trial. Ann Hematol. 2016;95(7):1169-76.

94. Tsujimoto K, Hata A, Fujita M, Hatachi S, Yagita M. Presepsin and procalcitonin as biomarkers of systemic bacterial infection in patients with rheumatoid arthritis. Int J Rheum Dis. 2016 [Epub ahead of print].

\section{Submit your next manuscript to BioMed Central and we will help you at every step:}

- We accept pre-submission inquiries

- Our selector tool helps you to find the most relevant journal

- We provide round the clock customer support

- Convenient online submission

- Thorough peer review

- Inclusion in PubMed and all major indexing services

- Maximum visibility for your research

Submit your manuscript at www.biomedcentral.com/submit
C Biomed Central 